\title{
Periodontal Health vs. Various Preventive Means in Toy Dog Breeds
}

\author{
Igor Capík \\ Department of Small Animals, University of Veterinary Medicine in Košice, Slovak Republic
}

Received June 29, 2009

Accepted June 15, 2010

\begin{abstract}
This study used six toy Chihuahua dogs in relationship. They underwent four 8 week periods differing in type of food (dry, soft, dental diet) and preventive means of periodontitis (toothbrushing and enzymatic chewing strips). The results showed nonsignificant influence of food consistency on dental plaque, calculus and gingivitis scores. Dental diet nonsignificantly decreased dental calculus deposition in comparison to common commercial food. The best results were achieved with toothbrushing. The enzymatic chewing strips significantly decreased dental plaque, calculus and gingivitis scores only on carnassial teeth. These results confirm that there are no absolute preventive measures of periodontitis.
\end{abstract}

Dog, dental plaque, toothbrushing, dental diet, enzymatic chewing strips

Periodontal disease has been identified as the most common oral health problem in domestic dogs (Lund et al. 1999). Accumulation of supra-gingival and sub-gingival plaque on the tooth surface is responsible for the development of an inflammatory reaction of the periodontal tissues. It is more severe in small breed dogs and the prevalence of periodontal disease increases with age. All dogs with inadequate oral hygiene will develop gingivitis often progressing to periodontitis with potential severe destruction of tooth-supporting tissues. Mechanical tooth-brushing continues to be the most effective oral hygiene in humans with optimum frequency twice a day. Also in dogs, the plaque control is best achieved by regular tooth-brushing. The effectiveness of tooth-brushing is linked to the frequency and quality of this activity.

Periodontal disease may be related to the texture of the diet and it is generally accepted that an abrasive, more fibrous diet, is beneficial to periodontal health (Wats on 1994). The anti-plaque effect of chewing on a fibrous diet was studied in dogs in the 1960s. The effect of adding a hygiene chew with a flexible, rubbery consistency has also been demonstrated in the dog (Gorrel and Bierer 1999). Over the years, many therapeutic and preventive interventions have been developed for periodontal disease, but evidence of effectiveness is highly variable.

The purpose of the study reported here was to compare the plaque and dental calculus reduction effect of various preventive means including tooth-brushing, dental diet and commercial dental chewing strips.

\section{Materials and Methods}

The study was conducted at the Clinic of Small Animals, University of Veterinary Medicine Košice, Slovak Republic. Six toy breed dogs (Chihuahua), 1 male and 5 females, were used in the study. The same dogs were used throughout the study to exclude individual differences among dogs in different groups. The weight of dogs ranged from 1.9 to $2.9 \mathrm{~kg}$ and their age was 3 (three dogs), 4, 6 and 7 years. The dogs included in the study suffered from marginal gingivitis and periodontitis of the first to third grade in some regions of the dental arcade. For all teeth the scored periodontal probing depth (PPD) did not exceed $2 \mathrm{~mm}$ and there was only $2 \mathrm{~mm}$ measurable loss of gingival attachment on maxillary carnassials teeth in the oldest dog (7 years old), determined by probing attachment level (PAL), using the cemento-enamel junction as a reference point. The dogs were considered in good health based on physical examination and serum biochemistry tests. Before including them in the study and in the beginning of each study period, their teeth were cleaned using ultrasonic cleaning device. All dogs were

Address for correspondence:

doc. MVDr. Igor Capík, Ph.D

Univerzita veterinárskeho lekárstva, Klinika malých zvierat

Komenského 73, 04001 Košice

Phone: +421903130479

Slovenská republika

http://www.vfu.cz/acta-vet/actavet.htm 
subjected to 4 subsequent periods lasting 8 weeks (56 days) and differing in the strategy aimed at prevention of periodontal disease:

1) Feeding moistened commercial food (2616 adult, PLB International Inc., Boucherville, Canada) and brushing one half (right side) of the dentition once a week.

2) Feeding the same dry commercial food and brushing one half (right side) of the dentition once a week.

3) Feeding special dental diet without tooth-brushing (Canine t/d Hill's)

4) Feeding moistened and dry commercial diet once a day and giving chewing strips (OROZYME Canine S, CARDON Pharmaceutical N.V. Belgium) for the rest of the day, half of the chewing strip for dogs of small breeds.

After 56 days, the dogs were anaesthetized using diazepam $0.5 \mathrm{mg} / \mathrm{kg}$ with butorphanol $0.1 \mathrm{mg} / \mathrm{kg}$ b.w., followed immediately by propophol $3 \mathrm{mg} / \mathrm{kg}$ b.w., i.v. Anaesthesia was maintained using isoflurane inhalation. Photographs of dentition were taken before the procedure, after staining the teeth with fluorescein dye with the aim to visualise dental plaque deposition and following tooth-brushing to remove dental plaque to assess calculus deposition. Photographs were evaluated and the results compared among dogs.

Teeth to be scored for plaque, calculus and gingivitis were: upper dental arcade: 103, 203, 104, 204, 108, 208 and lower dental arcade: 304, 404, 308, 408, 309, 409.

The buccal surface was evaluated and scored. Plaque, calculus and gingivitis scoring systems were used.

Plaque scoring system: Turesky modification of Quigley-Hein Plaque Index (0 - 5)

$0=$ No plaque

$1=$ Isolated islands of plaque at the cervical margin of the tooth

$2=$ A continuous band of plaque narrower than $1 \mathrm{~mm}$ at the cervical margin

$3=\mathrm{A}$ band of plaque wider than $1 \mathrm{~mm}$ and narrower but covering less than $1 / 3$ of the crown

$4=$ Plaque covering at least $1 / 3$ and less than $2 / 3$ of the tooth crown

$5=$ Plaque covering $2 / 3$ and more of the tooth crown

Calculus scoring system: Modification of Ramfjord Calculus Index ( $0-4)$

$0=$ no visible calculus

$1=$ scant areas of supragingival calculus, not forming a continuous band along gingival margin

$2=$ supragingival calculus covering up to the gingival $1 / 3$ of the crown

$3=$ supragingival calculus covering up to $2 / 3$ of the crown

$4=$ supragingival calculus covering more than $2 / 3$ of the crown

Gingivitis scoring system: Loe and Silness modification method $(0-4)$

$0=$ normal, no gingivitis

$1=$ very mild gingivitis, red, swollen but no bleeding on probing

$2=$ mild gingivitis, red, swollen and delayed bleeding on probing

$3=$ moderate gingivitis as before but immediate bleeding on probing

4 = severe gingivitis, ulceration, spontaneous haemorrhage and profuse bleeding on probing

Statistic MANOVA (Multivariate analysis of variance - statistical significance of two and more vector averages) was used to test for significance of mean differences of 3 variables ( $p$ - plaque, $c$ - calculus, $g$ - gingivitis) for 2 within subjects effects - treatment (with levels: $1=$ soft food, $2=$ dry food, $3=$ dental diet, $4=$ orozyme) and side (with levels 1 = left, 2 = right).

Repeated measures ANOVA were used to determine which variable/s cause/s significance (Analysis of variance - statistical significance of two and more averages).

\section{Results}

Dogs from the groups fed soft or dry food and subjected to weekly cleaning of dental plaque deposition reached similar mean scores (Fig. 1). Tooth-brushing once a week had no general positive influence on dental plaque deposition between these two groups of dogs following application of disclosing solution. The mean dental plaque scores ranged from 2.5 to 4.6 with no significant difference between sides in individual dogs. Though the dental plaque score did not differ, an increased inflammatory gingival reaction was seen on the left - non-brushed side. Incisors showed the most pronounced difference in the dental plaque deposition between the two groups ( Tab 1).

Dental calculus deposition scores showed more distinct differences among the groups (Fig. 2). The right tooth-brushed dental arcades in the groups fed soft and dry food showed lower scores. In the dogs fed soft food, the dental calculus score ranged from 1.2-1.8 on the cleaned and from 1.7-2.3 on the non-cleaned side. Dogs on dry food showed lower tendency for dental calculus deposition with scores ranging from 1-1.5 on the cleaned and 


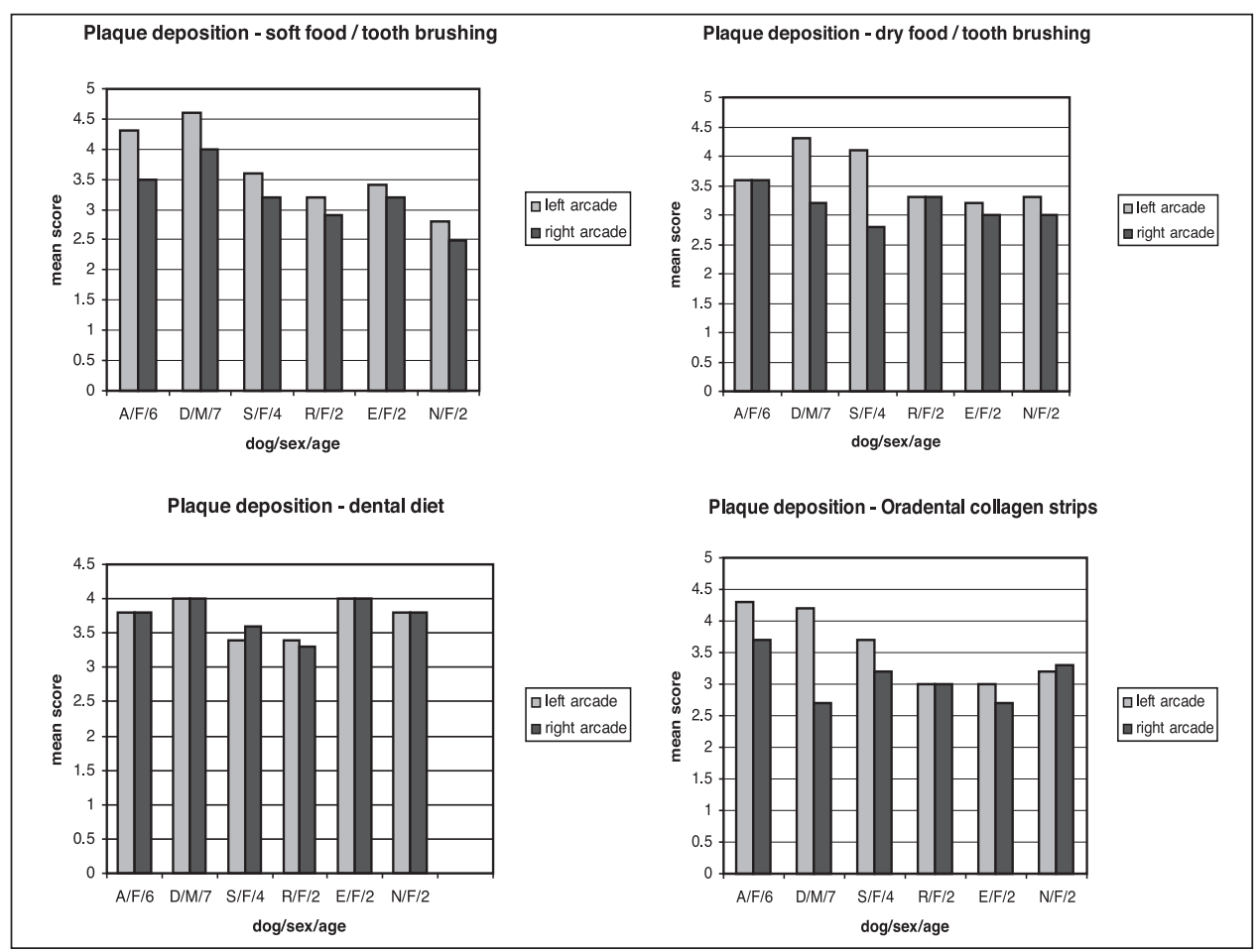

Fig.1 Mean plaque deposition scores related to different food and dental hygiene of individual dogs

Table 1. Comparison of dental plaque deposition among different types of teeth (identification by modified Triadan system)

\begin{tabular}{|l|c|c|c|c|c|c|}
\hline $\begin{array}{l}\text { Soft food } \\
\text { Left arcade }\end{array}$ & 203 & 204 & 208 & 304 & 308 & 309 \\
\hline Mean score & 3.5 & 3.33 & 4.16 & 3.83 & 3.83 & 3.83 \\
\hline Right arcade & 103 & 104 & 108 & 404 & 408 & 409 \\
\hline Mean score & 2.5 & 2.5 & 4 & 2.66 & 3.66 & 4.16 \\
\hline Dry food Left arcade & 203 & 204 & 208 & 304 & 308 & 309 \\
\hline mean score & 3.33 & 3.66 & 3.83 & 3.5 & 3.83 & 4.33 \\
\hline Right arcade & 103 & 104 & 108 & 404 & 408 & 409 \\
\hline Mean score & 2.5 & 2.5 & 3.5 & 2.83 & 3.83 & 3.5 \\
\hline Dental diet Left arcade & 203 & 204 & 208 & 304 & 308 & 309 \\
\hline Mean score & 3.16 & 3.66 & 4.66 & 3.5 & 4.33 & 4 \\
\hline Right arcade & 103 & 104 & 108 & 404 & 408 & 409 \\
\hline Mean score & 3.16 & 3.66 & 4.5 & 3.66 & 4.0 & 4.33 \\
\hline Oradental Left arcade & 203 & 204 & 208 & 304 & 308 & 309 \\
\hline Mean score & 3.66 & 3.5 & $2 / 3 *$ & 3.5 & $1.75 / 3.5 *$ & $2 / 3.5 *$ \\
\hline Right arcade & 103 & 104 & 108 & 404 & 408 & 409 \\
\hline Mean score & 3 & 3.33 & $1.75 / 3.16 *$ & 3.16 & $2 / 3 *$ & $1.5 / 2.83 *$ \\
\hline
\end{tabular}

* dental plaque deposition in individuals refusing to chew dental strips 

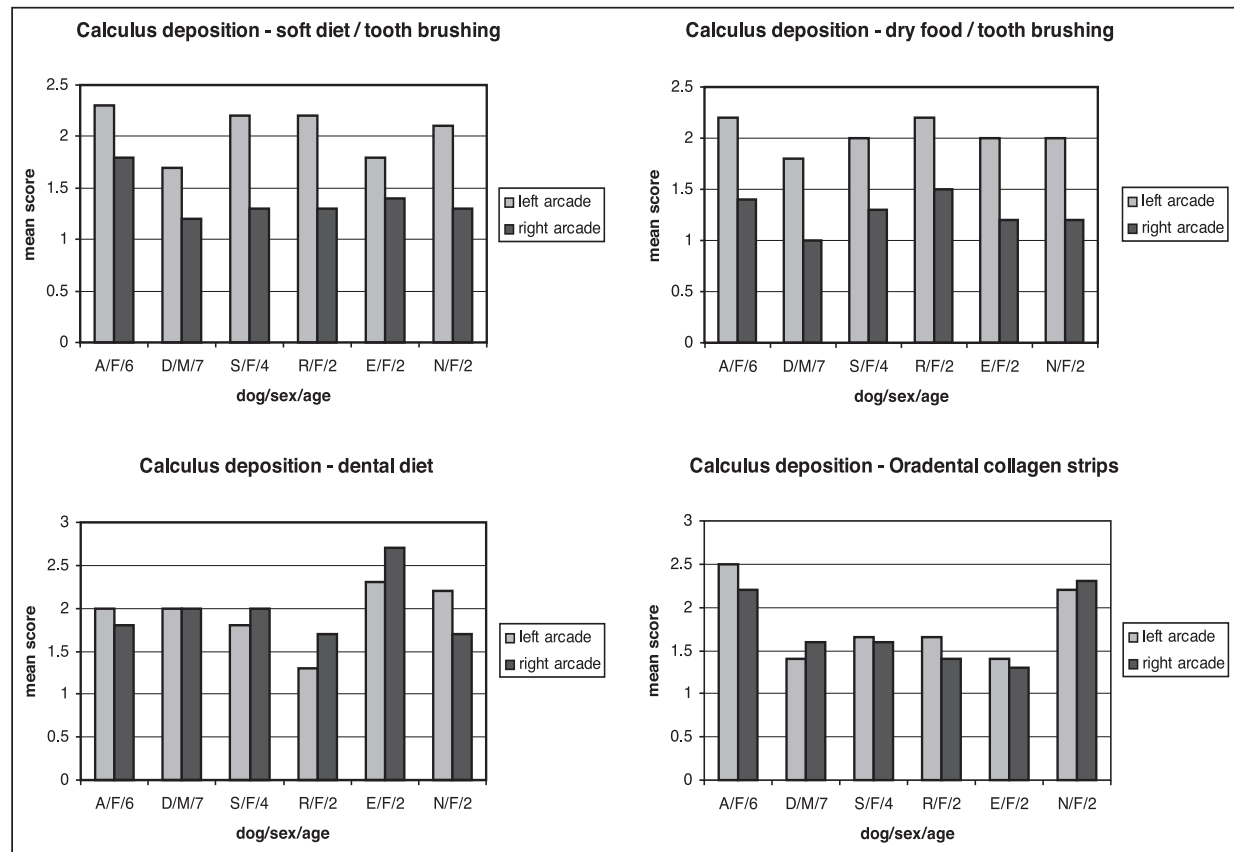

Calculus deposition - Oradental collagen strips

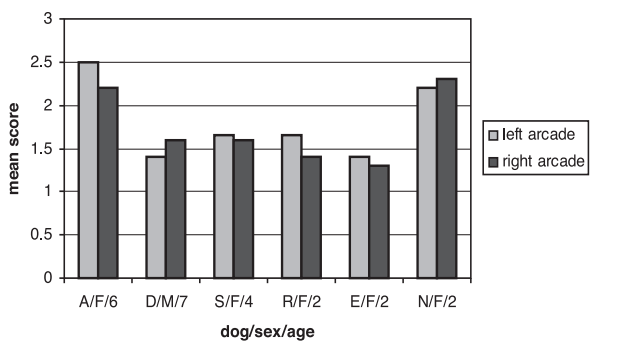

Fig. 2. Mean calculus deposition scores related to different food and dental hygiene of individual dogs

Table 2. Comparison of dental calculus deposition among different types of teeth (identification by modified Triadan system).

\begin{tabular}{|l|c|c|c|c|c|c|}
\hline $\begin{array}{l}\text { a/ Soft food } \\
\text { Left arcade }\end{array}$ & 203 & 204 & 208 & 304 & 308 & 309 \\
\hline Mean score & 1 & 2 & 2.66 & 1.83 & 2.33 & 2.5 \\
\hline Right arcade & 103 & 104 & 108 & 404 & 408 & 409 \\
\hline Mean score & 0.33 & 1.33 & 2.33 & 1.33 & 1.5 & 1.5 \\
\hline b/ Dry food Left arcade & 203 & 204 & 208 & 304 & 308 & 309 \\
\hline Mean score & 1.83 & 2.5 & 2.83 & 1.83 & 1.5 & 1.83 \\
\hline Right arcade & 103 & 104 & 108 & 404 & 408 & 409 \\
\hline Mean score & 0.66 & 0.83 & 2.16 & 1 & 1 & 1 \\
\hline c/ Dental diet Left arcade & 203 & 204 & 208 & 304 & 308 & 309 \\
\hline Mean score & 1.83 & 2.16 & 2.5 & 1.66 & 1.66 & 1.83 \\
\hline Right arcade & 103 & 104 & 108 & 404 & 408 & 409 \\
\hline Mean score & 1.66 & 1.66 & 2.66 & 2 & 2 & 1.66 \\
\hline d/ Oradental Left arcade & 203 & 204 & 208 & 304 & 308 & 309 \\
\hline Mean score & 1.5 & 2.16 & $0.75 / 1.5$ & 2.66 & $0.5 / 1$ & $0.5 / 1$ \\
\hline Right arcade & 103 & 104 & 108 & 404 & 408 & 409 \\
\hline Mean score & 1.33 & 2 & $0.75 / 1.66$ & 2 & $0.5 / 1$ & $0.5 / 1$ \\
\hline
\end{tabular}

1.8-2.2 on the non-cleaned side. When expressed in percentage, tooth-brushing decreased calculus deposition by $21.7-29.4 \%$ when feeding soft food and by $31.8-33.3 \%$ with dry food. These results confirmed a minimum effect of hard and soft consistency of commercial food on dental calculus deposition. Tooth-brushing once a week generally decreased dental calculus deposition although there was also individual predisposition among the 


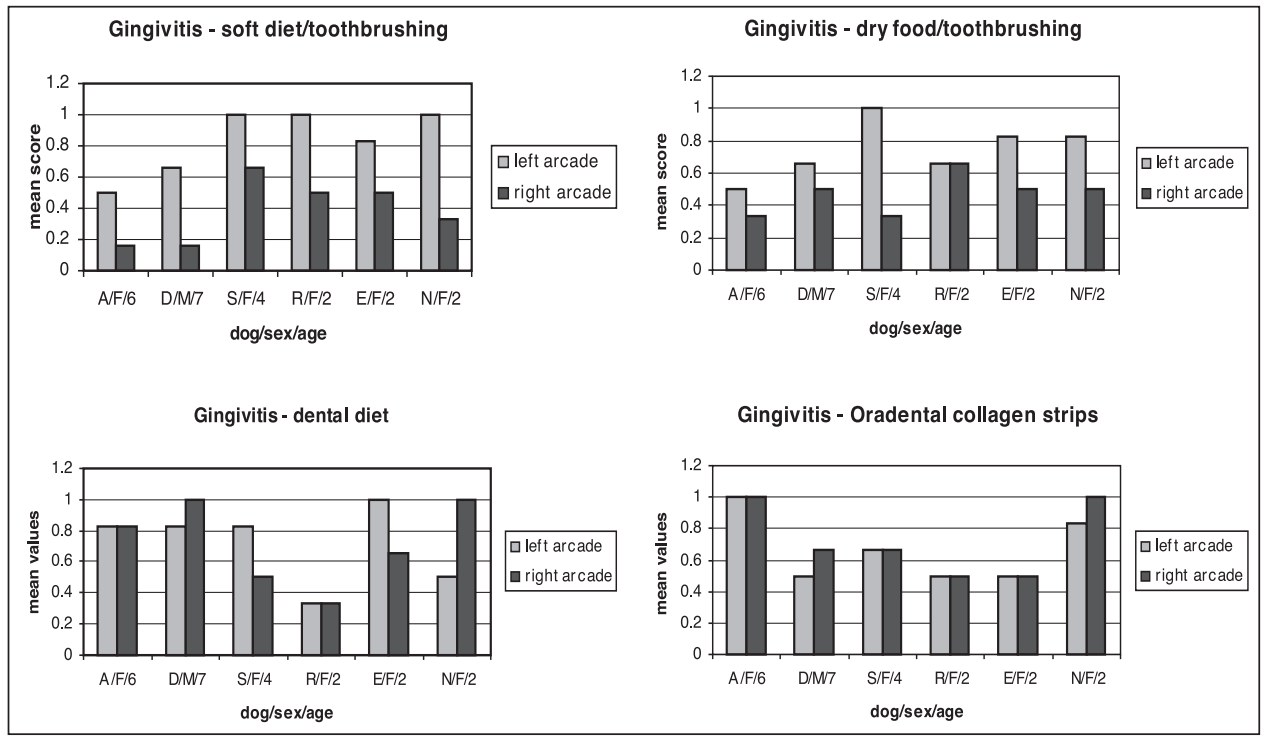

Fig. 6. Mean gingivitis scores related to different food and dental hygiene of individual dogs.

Table 3. Comparison of gingivitis among different types of teeth (identification by modified Triadan system).

\begin{tabular}{|l|c|c|c|c|c|c|}
\hline $\begin{array}{l}\text { a/ Soft food } \\
\text { Left arcade }\end{array}$ & 203 & 204 & 208 & 304 & 308 & 309 \\
\hline Mean score & 0.83 & 1 & 1 & 0.83 & 0.83 & 0.66 \\
\hline Right arcade & 103 & 104 & 108 & 404 & 408 & 409 \\
\hline Mean score & 0.16 & 0.16 & 0.5 & 0.33 & 0.66 & 0.5 \\
\hline b/ Dry food Left arcade & 203 & 204 & 208 & 304 & 308 & 309 \\
\hline Mean score & 0.83 & 0.83 & 1 & 0.66 & 0.66 & 0.5 \\
\hline Right arcade & 203 & 204 & 208 & 304 & 308 & 309 \\
\hline Mean score & 0.33 & 0.66 & 0.83 & 0.66 & 0.66 & 0 \\
\hline c/ Dental diet Left arcade & 203 & 204 & 208 & 304 & 308 & 309 \\
\hline Mean score & 0.83 & 1 & 1 & 0.33 & 0.66 & 0.5 \\
\hline Right arcade & 103 & 104 & 108 & 404 & 408 & 409 \\
\hline Mean score & 0.5 & 0.66 & 1 & 0.66 & 0.83 & 0.66 \\
\hline d/ Oradental Left arcade & 203 & 204 & 208 & 304 & 308 & 309 \\
\hline Mean score & 1 & 1 & 0.33 & 1 & 0.5 & 0.16 \\
\hline Right arcade & 103 & 104 & 108 & 404 & 408 & 409 \\
\hline Mean score & 1 & 1 & 0.66 & 1 & 0.33 & 0.33 \\
\hline
\end{tabular}

dogs (Fig. 3). In different types of teeth, the mean dental calculus score ranged on the right side from 0.33 to 2.33 and on the left side from 1 to 2.66 in the soft diet group. In the dry diet group the mean score ranged from $0.66-2.16$ and $1.83-2.83$, respectively (Table 2).

The group of dogs fed the special dental diet without tooth-brushing showed similar calculus deposition as the previous groups with minimal or zero differences between dental arcades.

The mean dental calculus score ranged from 1.3-2.66. Predisposition for advanced dental calculus deposition including incisors was diagnosed in one dog (Plate XIII, Fig. 4). 
In the fourth group fed soft/hard food and chewing dental strips the mean scores of calculus deposits ranged between 1-2.5. The results in individuals were more diverse, related to willingness of dogs to chew dental strips. In dogs that chew willingly collagen strips, the carnassial teeth had minimum tendency for calculus deposition, but calculus deposition on the frontal teeth of these dogs showed similar calculus deposition scores as those in other groups (Plate XIV, Fig. 5). Some dogs in this group refused to chew collagen strips which resulted in extensive calculus deposition on their teeth.

The gingivitis scores showed some differences among the groups of dogs. Tooth-brushing influenced positively the gingival inflammatory reaction despite plaque and calculus depositions. The gingivitis scores differed markedly in the group of dogs fed soft food and subjected to tooth-brushing (Plate XIII, Fig 3, Table 3).

Repeated measurements MANOVA were used to test for significance of mean differences of 3 variables ( $\mathrm{p}$ - plaque, c - calculus, $\mathrm{g}$ - gingivitis) for 2 Within Subjects Effects treatment (with levels: $1=$ soft food, $2=$ dry food, $3=$ dental diet, $4=$ orozyme collagen strips) and side (with levels $1=$ left, 2 = right).

Since the treatment $(P$-value $>0.05), 4$ means that the vectors do not differ significantly at 5\% alpha (Table 4). Conclusions are the same using other 3 MANOVA statistics.

Table 4. MANOVA

\begin{tabular}{|l|c|c|c|c|c|}
\hline Effect & Wilks' Lambda & F & Hypothesis df & Error df & $P$ \\
\hline treatment & 0.479 & 1.248 & 9.000 & 31.789 & 0.302 \\
\hline side & 0.029 & 33.966 & 3.000 & 3.000 & 0.008 \\
\hline
\end{tabular}

Table 5. ANOVA (side)

\begin{tabular}{|l|c|c|}
\hline Measure & $\mathrm{F}$ & $P$ \\
\hline $\mathrm{P}$ & 10.057 & 0.025 \\
\hline $\mathrm{C}$ & 74.536 & 0.000 \\
\hline $\mathrm{G}$ & 13.442 & 0.014 \\
\hline
\end{tabular}

$\mathrm{P}$ - plaque, $\mathrm{C}$ - calculus, $\mathrm{G}$ - gingivitis 0.05 ) (Table 5)
Because the side $(P$-value $<$ $0.05)$, at least one of 3 variables' means differed significantly between the left and right sides at $5 \%$ alpha.

Repeated measures ANOVA were used to determine which variable/s cause/s significance. All 3 variables $(\mathrm{P}-$ plaque, $\mathrm{C}-$ calculus, $\mathrm{G}-$ gingivitis $)$ were significant $(P<$

Fig. $7 \mathrm{a}$ confirms nonsignificant interaction between the side and treatment means in relation to dental plaque deposition.

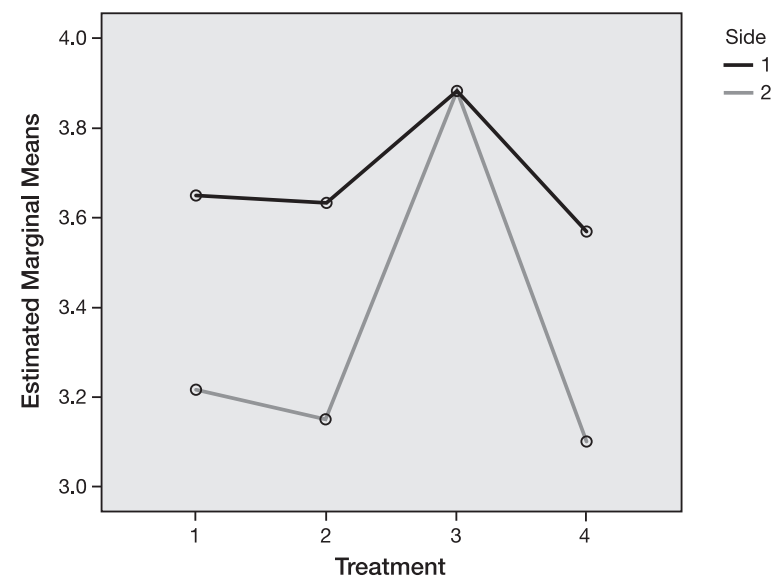

Treatment 1 - soft food, 2 - dry food, 3 - dental diet, 4 - chewing strips

a/ Dental plaque deposition scores

Fig. 7a,b,c. Interaction between the side and treatment means. 


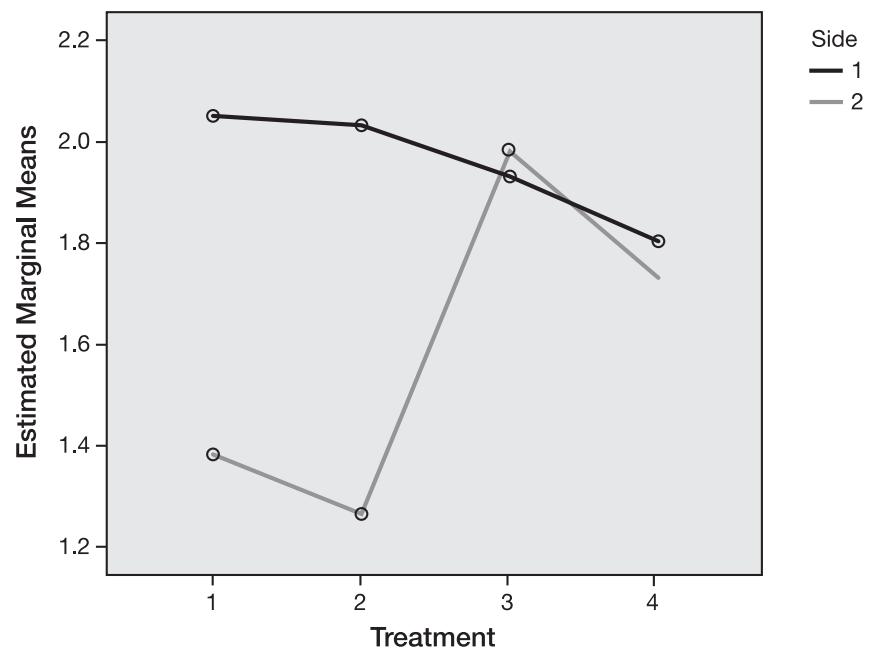

Treatment 1 -soft food, 2 - dry food, 3 - dental diet, 4 - chewing strips

b/ Dental calculus scores

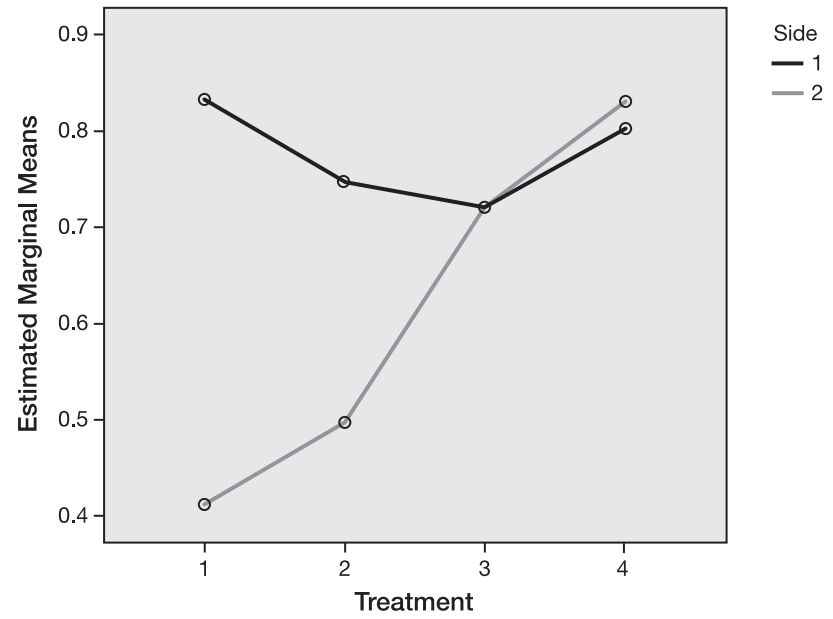

Treatment 1 - soft food, 2 - dry food, 3 - dental diet, 4 - chewing strips c/ Gingivitis scores

Fig. 7a,b,c. Interaction between the side and treatment means.

Interaction between the side and treatment means was significant in relation to dental calculus and gingivitis scores in the first two groups of dogs (Figs 7b,c). Nonsignificant differences in the dental calculus and gingivitis scores were observed in general in the other two groups. In the fourth group of dogs treated by Orozyme collagen chewing strips, an excellent curative effect was achieved on the sectorial (carnassial) teeth while other teeth included in the assessment showed no effect of chewing strips (Tables 2 and 3, Fig. 5). 


\section{Discussion}

The results obtained in this study confirmed the differences in dental calculus deposition among individuals in the group fed the same food. Dry commercial food compared to soft food had no significant effect on prevention of dental plaque and calculus deposition. Our results showed similar dental calculus deposition in the same individual fed soft or dry food.

Other important findings are related to the role of dental brush influence on maintenance of oral hygiene. Again, the individual predisposition for dental calculus deposition among individuals played a role together with the frequency of tooth-brushing. While in some dogs the weekly tooth-brushing decreased the dental calculus deposition, in other animals this frequency did not result in any difference between the brushed and non-brushed side of the dental arcade. Although there was no difference in the dental calculus deposition in some individuals, gingivitis as an accompanying clinical sign was seen on the non-brushed side. This confirms the theory that dental calculus without contaminated dental plaque does not cause gingivitis. Although the tooth-brushing in our study did not prevent equally the dental calculus deposition among the dogs, it provided decreased bacterial contamination of dental calculus and reduced gingival inflammatory reaction.

Special dental diet used in this study, as one of the factors influencing the rate of dental calculus deposition, failed to show a complex effect on the dentition. When used as the only way of periodontitis prevention, it appeared insufficient. The dental calculus deposition was similar as with other types of food. Our results do not correlate with the results published by Logan et al. (2002). They described 39\% and 36\% decrease in dental plaque and calculus accumulation and reduced gingivitis in the case of dental diet feeding in comparison with a typical dry dog food. The mean dental plaque and gingivitis scores in our study did not differ between commercial dry food and special dental diet. Logan et al. (2002) used in the study dogs with wide range of body weight (9.0 to $25 \mathrm{~kg}$ ), what would influence the results as the larger dog the lower predisposition to periodontitis.

Chewing strips used as the fourth way of prevention of periodontitis showed strictly localized effect on the dentition. Very good results were achieved only on the carnassial teeth. Other teeth showed similar dental plaque and calculus deposition as with other types of food. Our results do not correlate with the results published by Hennet (2001) and Gorrel et al. (1998). Hennet (2001) described a significant effect of enzymatic rawhide dental chews on dental plaque accumulation in 7-day study on twenty examined teeth (103, 203, 104, 204, 106, 206, 107, 207, 108, 208, 109, 209 and 304, 404, 306, 406, 307, 407, 308, 408, 309, 409).

Those results would be influenced by the age of dogs used in the study (13-22 months), the weight $(8.4-12.7 \mathrm{~kg})$ and the length of study ( 7 days). The results describe mean plaque score values not differentiating among group of teeth included in the study. Naturally, incisors and canines do not play an essential role in the chewing process, therefore there is higher predisposition for dental plaque accumulation as confirmed in our results.

Another limiting factor was the willingness of individuals to chew dental collagen strips. Some of the dogs refused to chew dental enzymatic strips from the beginning of the study. At the end of the study the willingness to chew the chewing strips subsided in some individuals. Our result suggested that the enzymatic chewing strips play more mechanical than enzymatic role in prevention of dental plaque and calculus accumulation.

Results obtained in our study showed that none of the diets and dental hygiene products provided full mouth elimination of periodontal health problems. Tooth-brushing provided the best general prevention of periodontal tissue inflammation and together with properly timing of professional periodontal prophylaxis represents the best way in preservation of oral health. The properly timed professional dental prophylaxis plays irrecoverable role 
in the prevention of development of advanced stages of periodontitis (Polkowska et al. 2003; Fichtel et al. 2005)

\section{Zdravotný stav parodontu vo vzt’ahu k účinku niektorých preventívnych prostriedkov u drobných plemien psov}

Parodontózy môžu súvisiet' so štruktúrou potravy a v tejto súvislosti bol sledovaný u psov antiplakový účinok žúvania a vláknitej potravy. Je vyvinutých viacero preventívnych spôsobov parodontóz u malých zvierat. V tejto práci bolo použitých šest' psov plemena čivava ktoré boli v príbuzenskom vzt’ahu. Podstúpili štyri osem týždňové sledovacie obdobia líšiace sa v type potravy (suchá, mokrá, suchá dentálna diéta) a v použití prevantívnych prostriedkov (mechanické čistenie zubnou kefkou, žúvanie enzymatických tyčiniek).

Výsledky poukazujú na nesignifikantný vplyv konzistencie potravy na tvorbu zubného plaku, kameňa a s tým súvisiacu gingivitídu v sledovanej skupine psov. Najlepšie všeobecné účinky boli dosiahnuté pri použití mechanického čistenia zubnou kefkou. Komerčne vyrábaná dentálna diéta nesignifikantne znížila tvorbu zubného kameňa v porovnaní z bežným krmivom. Enzymatické žúvacie tyčinky signifikantne znížili tvorbu zubného kameňa a s tým súvisiacu gingivitídu len na sektoriálnych zuboch čo poukazuje len na mechanický účinok čistenia. Tieto výsledky potvrdzujú skutočnost', neexistencie absolútneho spôsobu prevencie parodontóz. Mechanické čistenie zubnou kefkou doplnené periodickou profesionálnou terapiou predstavuje v súčasnosti najefektívneší spôsob.

\section{Acknowledgement}

This study was suported by the Scientific Grant Agency of the Ministry of Education of the Slovak Republic and the Slovak Academy of Sciences No.1/0559/09.

\section{References}

Lund EM, Armstrong PJ, Kirk LM, Kolar LM, Klauser JS 1999: Health status and population characteristics of dogs and cats examined at private veterinary practices in the United States. J Am Vet Med Assn 214: 13361341

Watson ADJ 1994: Diet and periodontal disease in dogs and cats. Australian Vet J 71: 313-318

Gorrel C, BiererR 1999: Long term effects of a dental hygiene chew on the periodontal health of dogs. J Vet Dent 16: $77-81$

Logan EI, Finney O, Hefferren JJ 2002: Effects of a dental food on plaque accumulation and gingival health in dogs. J Vet Dent 19: 15-18

Hennet P 2001: Effectiveness of an enzymatic rawhide dental chew to reduce plaque in Beagle dogs. J Vet Dent 18: $61-64$

Gorrel C, Inskeep G, Inskeep T 1998: Benefits of a "dental hygiene chew" in maintaining periodontal health in cats. J Vet Dent 15: 135-138

Fichtel T, Crha M, Langerová E 2005: The efficacy of methods used for enamel treatment in the dog: direct impact of damaged surface on the plaque reestablishment - REM study. Proceedings: $14^{\text {th }}$ European Congress of Veterinary Dentistry, Slovinsko, Ljubljana, 22-25. 9. 2005: pp 81-85

Polkowska I, Orzelski M 2003: The non-surgical treatment of periodontal disease in carnivores and maintenance therapy. Proceedings: $12^{\text {th }}$ European Congress of Veterinary Dentistry, Pisa: pp. 75-76 
Plate XIII

Capík I. et al.: Periodontal ... pp. 637-645
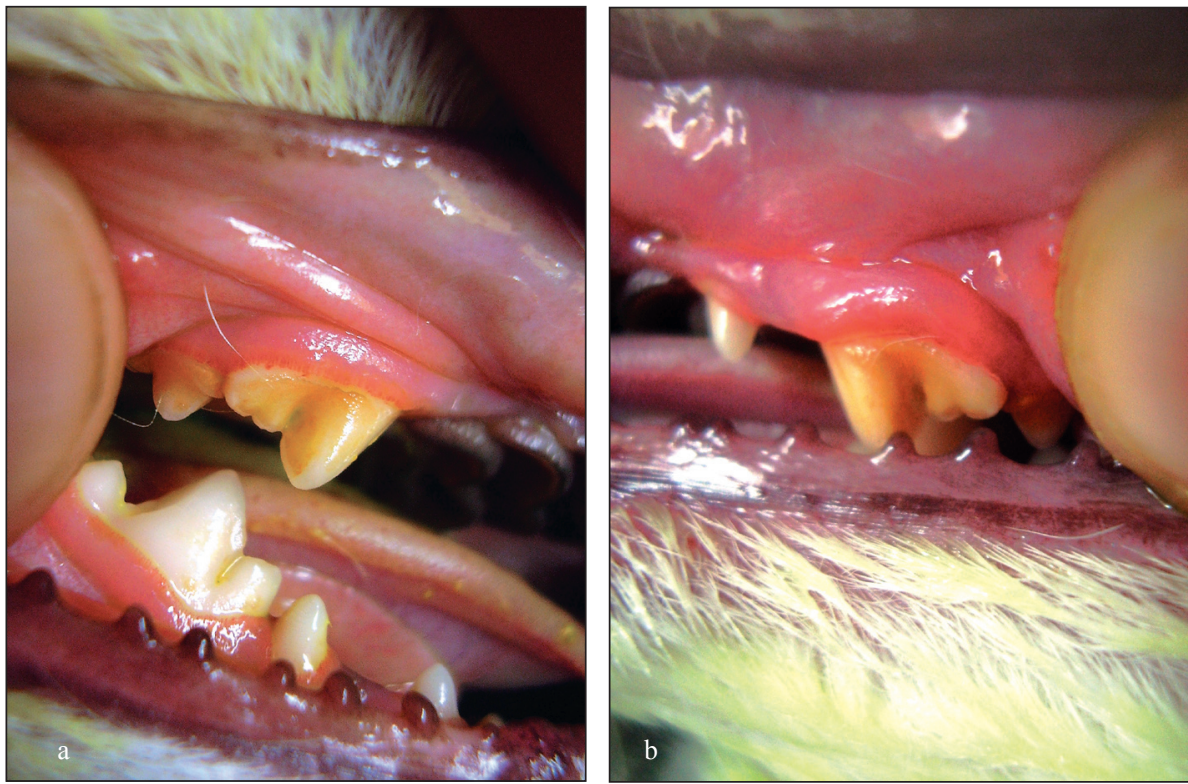

Fig. 3 a,b. The right side (a) toothbrushed one week did not differ from the uncleaned left side (b) in dental calculus score, but only the left side suffered from gingivitis.

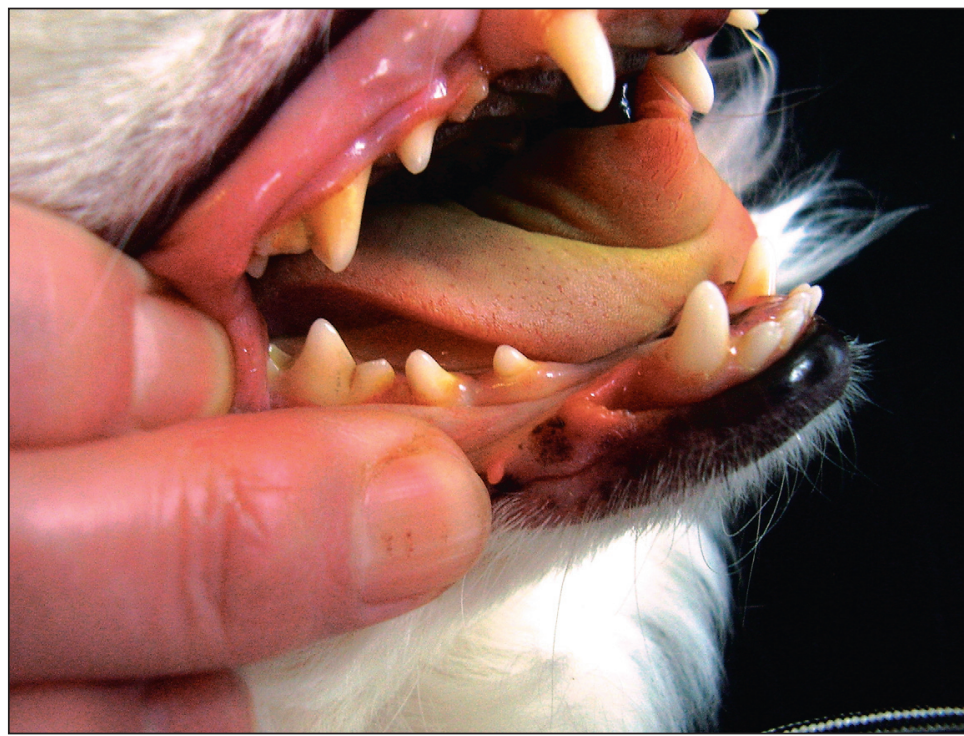

Fig. 4. One of dogs fed the dental diet with dental calculus deposition on most teeth. 

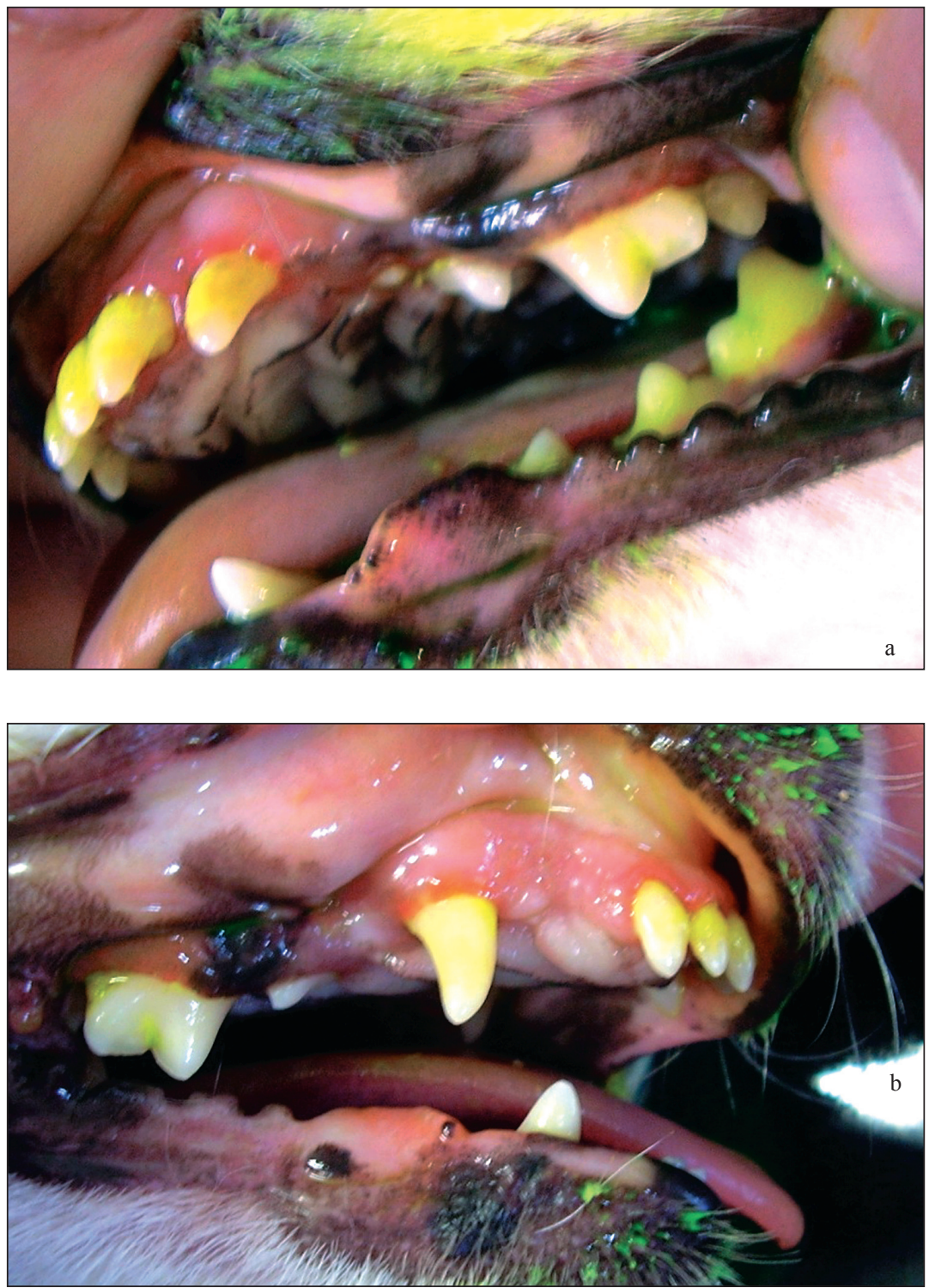

Fig. 5. Dental plaque and calculus deposition in the dog after the use of enzymatic collagen strips. Decreased scores on the carnassial teeth, but differences between left (a) and right (b) dental arcades are also seen. 